\title{
Optimization of laboratory requirements through experimental design for maximum growth of indigenous saccharomyces cerevisiae using apple waste as substrate
}

\author{
Faheem Ahmed Khan ${ }^{1,3}$, Sarzamin Khan ${ }^{2}$, Nafees Bacha* ${ }^{* 1}$, Tariq Khan ${ }^{1}$ \\ ${ }^{2}$ Centre of Biotechnology and Microbiology, University of Peshawar, Pakistan \\ ${ }^{2}$ Department of Poultry Sciences, Agriculture University, Peshawar, Pakistan \\ ${ }^{s}$ Department of Microbiology, University of Swabi, KPK, Pakistan
}

Key words: Sacharomyces cerevisiae, Apple waste, Amino acids, Single cell protein

http://dx.doi.org/10.12692/ijb/12.1.136-142 $\quad$ Article published on January 12, 2018

\begin{abstract}
From ancient wild type Saccharomyces Cerevisiae is used for production of valuable products. These microorganisms can be grown on a number of carbohydrate rich waste materials. For optimum valuable products It is needed to optimize different parameters for growth of indigenous $S$. cerevisiae utilizing apple waste. For the said purpose Indigenous $S$. cerevisiae was isolated from different fruit samples and identified by Polymerase chain reaction (PCR). Apple waste was collected and chemically treated to convert complex polysaccharide into simple one. For optimum growth, different laboratory parameters i.e.pH, temperature, shaking and glucose concentration were optimized using response surface methodology. Dry microbial biomass was analyzed for proximate composition i.e. crude protein, crude fibers, crude fats, total carbohydrates and ash contents. Dry microbial biomass was also evaluated for the presence of different amino acids through aminoacid analyzer using orthophthalaldehyde (OPA) as a fluorescent agent. Results revealed that $2.7 \%$ glucose, $32^{\circ} \mathrm{C}$ temperature, $\mathrm{pH} 5$ and shaking at $150 \mathrm{rpm}$ were best for optimum growth of indigenous $S$. cerevisiae. Dry microbial biomass was rich in crude proteins (44.65\%) followed by carbohydrate (43.09\%). It was observed that dry microbial biomass was rich in aspartic acid and leucine (14.57\%) each, followed by serine (12.89\%) and alanine (11.37\%).From the present study it is concluded that using response surface methodology different growth parameters can be optimized for indigenous $S$. cerevisiae on apple waste. Dry microbial biomass is rich in crude protein and essential amino acids therefore it can be used as a source of single cell protein.
\end{abstract}

*Corresponding Author: Nafees Bacha $₫$ nafeesbacha@uop.edu.pk 


\section{Introduction}

Agricultural activities and food processing plants generate a considerable amount of wastes materials, which are rich in organic materials and could be used for the synthesis of valuable products. During shipment and processing of apples about 30\% of waste materials is generated. In the environment, these waste materials possess a threat to humans because these can support the growth of many pathogenic microorganisms. Because these wastes are rich in carbohydrates, have high nutritional value and available in low cost or no cost, these can be used for the production of a variety of microorganisms (Imrie and Righelato, 1976; Haddadin et al., 1999; Paul et al., 2002).

Although proteins obtained from animal sources are classified as quality proteins (Saima et al., 2008), however, Single cell protein which is obtained by growing different microbes on cheap raw materials is an important optional protein because of higher protein content. These are also preferred because of high protein contents $(60-70 \%)$ of the cell, the short reproduction time of microbes leads to rapid increase in biomass(Bekatorou et al., 2006; Sivasankar, 2002).Moreover, selected microorganisms are also able to reproduce on cheap nutrient sources and can be easily harvested because of their large cellular mass by the process of centrifugation and vacuum filtration resulting in economical protein source.

The resulting protein is cheap having low or little cost with comparatively better nutritive value(Asad et al., 2000).Single cell protein contains high quantity of carbohydrates, fatty acid, protein, vitamins, and minerals as well as have similar amino acids composition to fish protein, therefore, it can be used as a source for human food as well as animal feeds(Jamal et al., 2008).

Central composite design (CCD) of response surface methodology is used to predict responses which are based on some sets of experiments, containing dependent and independent variables within a given range.
In past response surface methodology was utilized for production of metabolites, optimization of microbial growth and optimization of microbial media (Vazquez and Martin, 1998; Ramı́ rez et al., 2001; Li et al., 2002).

Keeping in view the value of microbial proteins, the present research work was designed to isolate indigenous $S$. cerevisiae from different fruit samples. To evaluate the possible use of apple wastes for optimum production of microbial biomass. To optimizing different parameters like glucose concentration, shaking, incubation temperature and $\mathrm{pH}$ of the medium using response surface methodology, as well as to evaluate the dry biomass for proximate composition and amino acids profile.

\section{Materials and methods}

Isolation and identification of indigenous $S$. cerevisiae

Indigenous $S$. cerevisiae was isolated from different fruit sources, identified physiologically and biochemically (Barnett et al., 1983; Kurtzman et al., 2011)and then through Polymerase Chain Reaction (PCR) by identification of $S$. cerevisiae specific 301bp sequence (Martorell et al., 2005). Isolated $S$. cerevisiae was then maintained by subculturing periodically.

\section{Collection and preparation of substrates}

After collection, apple wastes were washed with distilled water and then cut into small pieces. Waste were then boiled for 10 minutes in a specific amount of distilled water and then blended in a clean blender to make the slurry.

The slurry material obtained was then treated with chemicals to obtain more available sugars from complex polysaccharides (Bacha et al., 2011). The substrate was then diluted with distilled water and used in different sets of experiments to produce microbial biomass. 
Optimization of growth parameters for optimum production of yeast biomass

For optimum production different parameters such as $\mathrm{pH}$, temperature, shaking and glucose concentration were optimized in the media containing $10 \%$ substrate, $1 \%$ yeast extract and $0.5 \%$ ammonium nitrate using the statistical approach of response surface methodology. For graphical and statistical analysis JMP 12.1.osoftware was used in the study. A2 4 rotatable central composite design was adopted consisted of 26 sets of experiments with different combinations of variables. To confirm the production of optimum microbial biomass, anew experiment was performed under the optimum conditions as predicted by the model. After successful optimization microbial biomass was then harvested and dried in a hot air oven at $70^{\circ} \mathrm{C}$ for 48 hours (Ojokoh and Uzeh, 2005).

\section{Proximate analysis of dry microbial biomass}

On the basis of dry matter, single cell protein was then subjected to proximate analysis consisted of crude protein, ash contents, crude fat, and carbohydrate. All experiments were performed in triplicates and mean values were recorded (AOAC, 2006).

\section{Amino acids profile of dry microbial biomass}

To evaluate amino acid profile dried microbial cells were crushed in a pestle and mortar, after crushing cells were hydrolyzed with $10 \mathrm{~N}$ Hydrochloric acid (HCL) and was evaluated for the presence of amino acids using amino acid analyzer with post-column derivatization with the use of Ortho Phthalaldehyde (OPA) that forms conjugation with primary amines and produce fluorescent which is then detected (Ishida et al., 1981).

\section{Results and discussion}

Optimization of various parameters using response surface methodology

In response surface methodology all variables i.e. Glucose concentration, $\mathrm{pH}$, Shaking, and temperature were taken at a central value considered as zero.

Variables are set to their minimum and maximum values as shown in Table 1.

Table 1. Independent variables along with their minimum and maximum values.

\begin{tabular}{lcccc}
\hline Values & $\mathrm{pH}$ & Glucose concentration $(\mathrm{g})$ & Shaking $(\mathrm{rpm})$ & Temperature $\left({ }^{\circ} \mathrm{C}\right)$ \\
\hline Minimum & 3 & $\mathrm{O}$ & 100 & 25 \\
\hline Maximum & 7 & 5 & 200 & 35 \\
\hline
\end{tabular}

Full experimental plan and results of central composite design to studying the effect of 4 different variables along with produced microbial biomass are shown in Table 2. Surface plots along with contour plots are presented in Fig. 1. According to the present central composite design maximum biomass (5.04g/l) was obtained at glucose concentration $2.7 \%, \mathrm{pH} 5$, shaking 150 RPM and temperature $32^{\circ} \mathrm{C}$ which was higher than the biomass produced at $\mathrm{pH} 5$, shaking of $150 \mathrm{RPM}$ and temperature of $30^{\circ} \mathrm{C}$ i.e. $3.83 \mathrm{~g} / \mathrm{l}$.

Table 2. Experimental design along with microbial biomass.

\begin{tabular}{lccccc}
\hline S. no & Glucose $(\mathrm{g})$ & $\mathrm{pH}$ & Shaking $(\mathrm{RPM})$ & Temperature $\left({ }^{\circ} \mathrm{C}\right)$ & SCP \\
\hline 1 & $\mathrm{o}$ & 3 & 100 & 25 & 1 \\
\hline 2 & $\mathrm{o}$ & 3 & 100 & 35 & 1.3 \\
\hline 3 & $\mathrm{o}$ & 3 & 200 & 25 & 1.3 \\
\hline 4 & $\mathrm{o}$ & 3 & 200 & 35 & 1.4 \\
\hline 5 & $\mathrm{o}$ & 5 & 150 & 25 & 1.6 \\
\hline 6 & $\mathrm{o}$ & 7 & 100 & 35 & 1.5 \\
\hline 7 & $\mathrm{o}$ & 7 & 100 & 25 & 1.55 \\
\hline 8 & 0 & 7 & 200 & 35 & 1.3 \\
\hline 9 & 0 & 7 & 200 & & 1.25 \\
\hline
\end{tabular}




\begin{tabular}{|c|c|c|c|c|c|}
\hline 10 & 2.5 & 3 & 150 & 30 & 1.65 \\
\hline 11 & 2.5 & 5 & 100 & 30 & 1.65 \\
\hline 12 & 2.5 & 5 & 150 & 25 & 1.6 \\
\hline 13 & 2.5 & 5 & 150 & 30 & 1.7 \\
\hline 14 & 2.5 & 5 & 150 & 30 & 1.7 \\
\hline 15 & 2.5 & 5 & 150 & 35 & 1.7 \\
\hline 16 & 2.5 & 5 & 200 & 30 & 1.64 \\
\hline 17 & 2.5 & 7 & 150 & 30 & 1.35 \\
\hline 18 & 5 & 3 & 100 & 25 & 1.4 \\
\hline 19 & 5 & 3 & 100 & 35 & 1.4 \\
\hline 20 & 5 & 3 & 200 & 25 & 1.43 \\
\hline 21 & 5 & 3 & 200 & 35 & 1.5 \\
\hline 22 & 5 & 5 & 150 & 30 & 1.65 \\
\hline 23 & 5 & 7 & 100 & 25 & 1.3 \\
\hline 24 & 5 & 7 & 100 & 35 & 1.34 \\
\hline 25 & 5 & 7 & 200 & 25 & 1.32 \\
\hline 26 & 5 & 7 & 200 & 35 & 1.36 \\
\hline
\end{tabular}

Table 3. Amino acids profile of dry microbial biomass.

\begin{tabular}{lllc}
\hline S. \# & Amino acids & Symbol & Percent Concentration \\
\hline 1 & Aspartic acid & ASP & 14.57 \\
\hline 2 & Threonine & THR & 4.876 \\
\hline 3 & Serine & SER & 12.895 \\
\hline 4 & Glycine & GLY & 2.493 \\
\hline 5 & Alanine & ALA & 11.371 \\
\hline 6 & Valine & VAL & 5.765 \\
\hline 7 & Methionine & MET & 5.664 \\
\hline 8 & Isoleucine & ILE & 8.249 \\
\hline 9 & Leucine & LEU & 14.571 \\
\hline 10 & Tyrosine & TYR & 4.594 \\
\hline 11 & Phenylalanine & PHE & 3.329 \\
\hline 12 & Histidine & HIS & 2.084 \\
\hline 13 & Lysine & LYS & 8.79 \\
\hline 14 & Arginine & ARG & 0.752 \\
\hline 15 & Glutamic acid & GLU & 0 \\
\hline 16 & Proline & PRO & 0 \\
\hline
\end{tabular}

Proximate composition of dry microbial biomass on the basis of dry matter

Proximate composition of dry microbial biomass is shown in Fig. 2. Dry microbial biomass was rich in crude protein (44.65\%) followed by carbohydrates (43.09\%), ash contents (6.85\%), crude fiber (4.58\%) and crude fats (0.83\%). Bacha et al., 2002 conducted experiments on various agro-industrial wastes to produce microbial biomass, they reported $49.29 \%$ crude protein on total weight basis which supports our findings. OJOKOH and UZEH, 2005 also conducted experiments on the same matter utilizing papaya extracts they observed $35.5 \%$ crude proteins which are less than our observed value (44.65\%).
Amino acids profile of dry microbial biomass

Amino acids composition of dry microbial biomass is presented in Table 3. Results of amino acids analysis interpreted that there are substantial differences in amino acids composition of analyzed microbial proteins utilizing apple waste. A better level of leucine and aspartic acid i.e. $\mathbf{1 4 . 5 7 \%}$ each followed by Serine i.e. $12.89 \%$ was observed in dried microbial biomass. According to Fred and Peterson (1921), Kihlberg (1972) and Tannenbaum and Wang (1975) produced single cell protein was deficient in methionine while in this study it is observed that methionine was present in moderate quantity i.e. 5.66\%. On the other hand, proline and glutamic acid were absent in dry microbial biomass. 

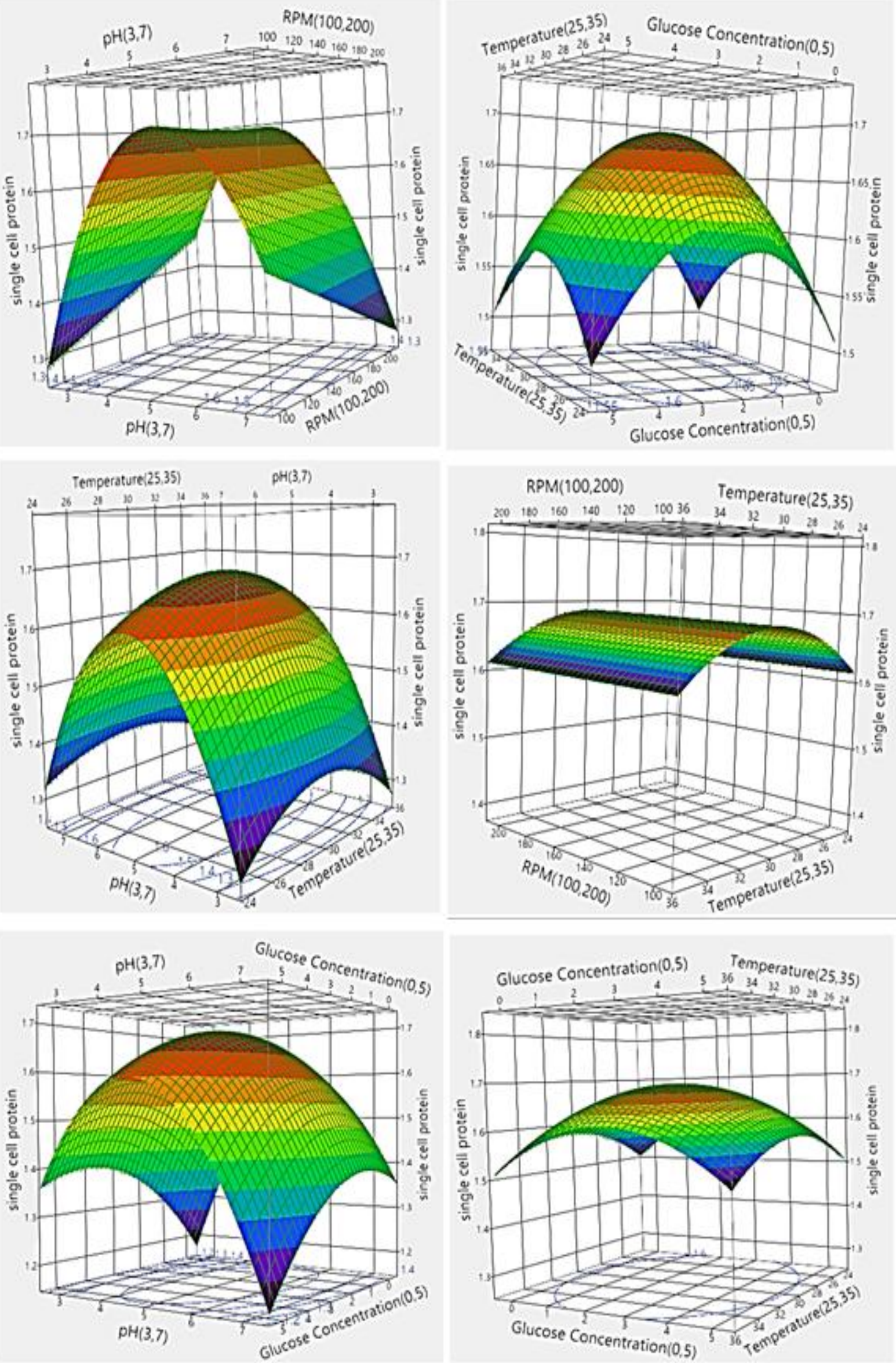

Fig. 1. Surface plots along with contour plots for dependent (SCP) and independent variables. 


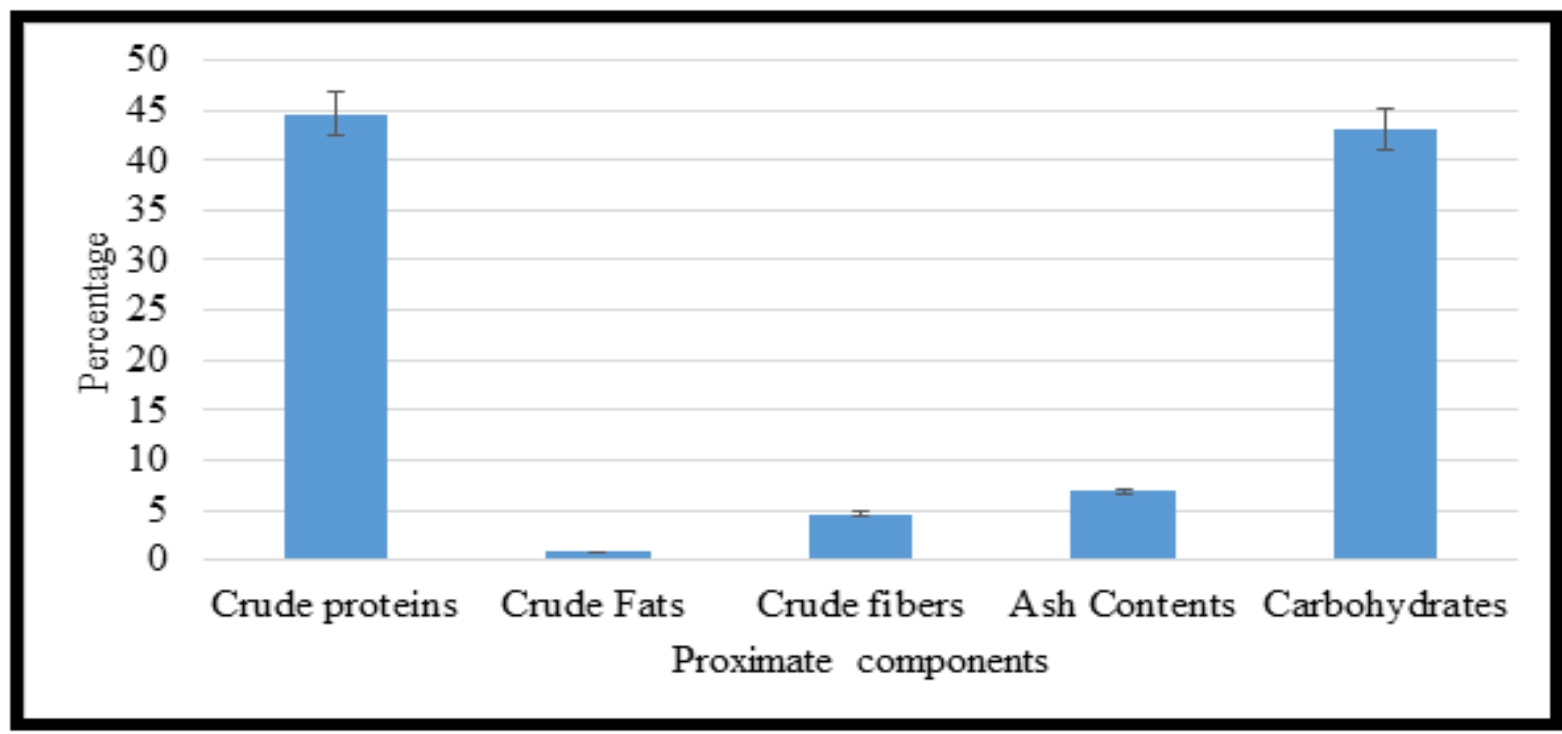

Fig. 2. Proximate analysis of microbial biomass produced on apples waste on dry matter basis.

\section{Conclusion}

From the present study, it is concluded that using response surface methodology different laboratory requirements can be optimized for indigenous $S$. cerevisiae onapple waste to produce optimum quantity of microbial biomass. Dry microbial biomass was rich in crude protein with variable level of amino acids. On the basis of these findings, drymicrobial biomass can effectively be used as protein source in animal and poultry feed to overcome protein deficiency.

\section{Acknowledgement}

We kindly acknowledge financial support from the Higher Education Commission H-9 Islamabad, Pakistan throughout the study.

\section{References}

Association of Official Analytical Chemist. 2006. The official methods of analysis of AOAC international. 18th edition Ed.; The Association of Official Analytical Chemists Arlington, U.S.A.

Asad MJ, Asghar M, Yaqub M, Shahzad K. 2000. Production of single cell protein from delignified corn cob by Arachniotus species. Pakistan Journal of Agricultural Sciences 37, 3-4.
Bacha U, Nasir M, Khalique A, Anjum A, Jabbar M. 2011. Comparative assessment of various agro-industrial wastes for Saccharomyces cerevisiae biomass production and its quality evaluation as single cell protein. Journal of Animal and Plant Sciences 21, 844-849.

Barnett JA, Payne RW, Yarrow D. 1983. Yeasts: Characteristics and identification Cambridge University Press.

Bekatorou A, Psarianos C, Koutinas AA. 2006. Production of food grade yeasts. Food Technology and Biotechnology 44, 407-415.

Fred E, Peterson W. 1921. Fermentation Process for the Production of Acetic and Lactic Acids from Corncobs. Industrial \& Engineering Chemistry 13, 211-213.

Haddadin MS, Abdulrahim SM, Al-Khawaldeh GY, Robinson RK. 1999. Solid state fermentation of waste pomace from olive processing. Journal of Chemical Technology and Biotechnology 74, 613-618.

Imrie F, Righelato R. 1976. Production of microbial protein from carbohydrate wastes in developing countries. Food from waste 79-94. 
Ishida Y, Fujita T, Asai K. 1981. New detection and separation method for amino acids by highperformance liquid chromatography. Journal of Chromatography A 204, 143-148.

Jamal P, Alam M, Salleh N. 2008. Media optimization for bioproteins production from cheaper carbon source. Journal of Engineering Science and Technology 3, 124-130.

Kihlberg R. 1972. The microbe as a source of food. Annual Reviews in Microbiology 26, 427-466.

Kurtzman C, Fell JW, Boekhout T. 2011. The yeasts: a taxonomic study: Elsevier.

Li C, Bai J, Cai Z, Ouyang F. 2002. Optimization of a cultural medium for bacteriocin production by Lactococcus lactis using response surface methodology. Journal of Biotechnology 93, 27-34.

Martorell P, Querol A, Fernández-Espinar M. 2005. Rapid identification and enumeration of Saccharomyces cerevisiae cells in wine by real-time PCR. Applied and environmental microbiology 71, 6823-6830.

Ojokoh A, Uzeh R. 2005. Production of Saccharomyces cerevisiae biomass in papaya extract medium. African Journal of Biotechnology 4, 12811284 .
Paul D, Mukhopadhyay R, Chatterjee BP, Guha AK. 2002. Nutritional profile of food yeast Kluyveromyces fragilis biomass grown on whey. Applied biochemistry and biotechnology 97, 209-218.

Ramı́ Rez J, Gutierrez H, Gschaedler A. 2001. Optimization of astaxanthin production by Phaffia rhodozyma through factorial design and response surface methodology. Journal of Biotechnology 88, 259-268.

Saima M, Akhter M, Khan U. 2008. Investigation on the availability of amino acids from different animal protein sources in golden cockerels. The Journal of Animal and Plant Sciences18, 53-56.

Sivasankar B. 2002. Food processing and preservation: PHI Learning Pvt. Ltd.

Tannenbaum SR, Wang DI. 1975. Single-cell protein II: MIT Press.

Vazquez M, Martin AM. 1998. Optimization of Phaffia rhodozyma continuous culture through response surface methodology. Biotechnology and bioengineering 57,314-320. 